Review

\title{
Slow Lives in the Fast Landscape: Conservation and Management of Plethodontid Salamanders in Production Forests of the United States
}

\section{Jessica A. Homyack ${ }^{1, \dagger, *}$ and Andrew J. Kroll ${ }^{2, \dagger}$}

1 Weyerhaeuser Company, Timberlands Technology, 1785 Weyerhaeuser Road, Vanceboro, NC 28586, USA

2 Weyerhaeuser Company, WTC 1A5, P.O. Box 9777, Federal Way, WA 98063, USA; E-Mail: aj.kroll@weyerhaeuser.com

$\dagger$ These authors contributed equally to this work.

* Author to whom correspondence should be addressed;

E-Mail: jessica.homyack@weyerhaeuser.com; Tel.: +1-252-633-7525; Fax: +1-252-633-7404.

External Editor: Deanna H. Olson

Received: 29 September 2014; in revised form: 4 November 2014 / Accepted: 5 November 2014 / Published: 17 November 2014

\begin{abstract}
Intensively-managed forest (IMF) ecosystems support environmental processes, retain biodiversity and reduce pressure to extract wood products from other forests, but may affect species, such as plethodontid salamanders, that are associated with closed canopies and possess limited vagility. We describe: (1) critical aspects of IMF ecosystems; (2) effectiveness of plethodontid salamanders as barometers of forest change; (3) two case studies of relationships between salamanders and coarse woody debris (CWD); and (4) research needs for effective management of salamanders in IMF ecosystems. Although plethodontid salamanders are sensitive to microclimate changes, their role as ecological indicators rarely have been evaluated quantitatively. Our case studies of CWD and salamanders in western and eastern forests demonstrated effects of species, region and spatial scale on the existence and strength of relationships between plethodontid species and a "critical" microhabitat variable. Oregon slender salamanders (Batrachoseps wrighti) were more strongly associated with abundance of CWD in managed second growth forests than ensatina salamanders (Ensatina eschscholtzii). Similarly, CWD was not an important predictor of abundance of Appalachian salamanders in managed hardwood forest.
\end{abstract}


Gaining knowledge of salamanders in IMF ecosystems is critical to reconciling ecological and economic objectives of intensive forest management, but faces challenges in design and implementation.

Keywords: intensive forest management; plantation; plethodontid; production forestry; salamander; woody debris

\section{Introduction}

Forest ecosystems are critical for global primary productivity, carbon storage and sustaining human populations [1]. Increased anthropogenic use, however, threatens forest ecosystems worldwide. In many areas, traditional forms of exploitation, such as over-harvesting of trees, remain primary threats [2]. However, additional forms of utilization (e.g., biomass harvesting, bushmeat hunting, firewood and food collection), conversion to alternative production uses (food crops for humans or livestock), loss (to expanding residential/commercial infrastructure) and inability to match regional supply and demand represent contemporary, acute stresses on forest ecosystems [2-7]. These changes have profound implications, as forests provide habitat for an estimated $80 \%$ of the world's terrestrial biodiversity [8] and contribute ecosystem services (e.g., clean air and water, recreation sites) valued at more than 16 trillion dollars USD [9].

Intensively-managed forest ecosystems (IMF) represent an opportunity to alleviate pressure on natural forests from existing or future stresses, especially relative to supplying wood products [10-12]. To realize the potential benefits of IMF ecosystems, an increased understanding is required of how specific practices affect habitat structures and cover types that support biological diversity [13]. For example, to produce commodities under contemporary restrictions on the expansion of area under management, IMF ecosystems in the "wood baskets" of the Pacific Northwest (PNW) and Southeastern (SE) United States depend on rapid regeneration of harvested stands and frequent stand turnover. Site preparation, planting of specific genotypes or clones and control of competing vegetation are critical tools for meeting production targets $[14,15]$. Implementing these tools at the harvest unit (i.e., stand) scale, combined with a reduction or absence of natural disturbances and application of forest practice regulations, creates novel landscape patterns that differ substantially from those created by historic disturbance regimes alone [16-18]. Increasing intensity of forest management, which compresses successional development, particularly the duration in which stands reside in mature structural stages, has unique implications for organisms with limited dispersal capabilities and slow rates of population growth, such as salamanders.

Salamanders in the family Plethodontidae occur primarily in forests of the New World and reach their greatest diversity in the United States in southeastern and northwestern forests [19,20]. Plethodontid salamanders are often abundant, constitute biomass in amounts comparable to mammals or birds, have broad functional roles as predator and prey and are morphologically and physiologically linked to cool and moist microhabitat types [20-23]. Collectively, these characteristics have garnered the attention of biologists interested in understanding broader ecological effects of forest disturbances, including timber harvesting and management. For example, given their ecology and life history characteristics, 
salamanders are often proposed as indicator species of environmental health, although a limited amount of empirical information is available to evaluate this claim [24-26]. Numerous experimental and observational studies have reported declines in abundance following a range of forest regeneration methods across North America (reviewed in [27,28]). Presumably, this response derives from a warmer and dryer microclimate after canopy removal, indicating that salamanders can be sensitive to a range of anthropogenic habitat alterations [29]. However, unified understanding of causes of variation in inter-specific and inter-eco-regional responses of salamanders to silvicultural practices or to specific attributes of managed forests is lacking [28,30].

Here, we describe contemporary patterns in IMF ecosystems and evaluate the use of plethodontid salamanders as effective barometers of how forest management affects conservation of biological resources [31,32]. To address this issue, we focus our discussion on temperate forests of the PNW and SE United States, given their global significance for wood production and as hotspots for terrestrial salamander diversity [20]. We explore use of plethodontid salamanders as indicators of forest ecosystem condition, including response to anthropogenic disturbances. Next, we present two case studies to explore responses of salamander populations to coarse woody debris (CWD), a structural component that is important for maintenance of many salamander populations and that is often altered by forest management. Given our findings, we make specific recommendations about research questions and appropriate study designs to inform policy development for best management practices and sustainability targets.

\section{IMF Ecosystems in Time and Space}

Historically, production of wood commodities relied on unregulated harvesting and passive regeneration practices distributed broadly across the forested land base [33,34]. In addition, given the volume of supply relative to demand, the harvesting pressure and levels of utilization were extremely variable spatially and temporally [35]. In contrast, IMF ecosystems produce wood from relatively uniform operational practices deployed across a restricted portion of the available forested land base [15]. Intensively-managed forest ecosystems often occur in landscapes with multiple ownerships that pursue different management objectives and, consequently, differing land use practices. Finally, regulations governing forestry operations and requirements of third-party sustainability certification programs interact with management objectives to shape the distribution of habitat structures and cover types across time and space in IMF landscapes [36]. To be successful, contemporary conservation and management initiatives must address these factors and the dynamic economic environment in which IMF ecosystems develop [10,37].

Regeneration practices in both the PNW and SE are orchestrated to produce high volume stands at harvest. Southern pine (loblolly pine, Pinus taeda; slash pine, P. elliottii; shortleaf pine; P. echinata; and longleaf pine, $P$. palustris) are common plantation species in the SE, whereas Douglas-fir (Pseudotsuga menziesii) is preferred in the PNW, with these species grown primarily for structural lumber (southern pine is used also for pulp). Loblolly pine is the most common SE planted species, with $\approx 14$ million ha in plantations, due to their wide tolerance and high growth rates $[15,38]$. Stand turnover in pine plantations is more frequent in the SE due to the rapid maturity of southern pine stands ( 25-35 years vs. $\sim 50$ years for Douglas-fir). In both regions, selected nursery stock is planted at 
relatively uniform densities to achieve desired stocking rates and fertilized to accelerate growth. Although herbicides are used for site preparation and vegetation control in Douglas-fir plantations, combinations of both herbicide and mechanical site preparation frequently occur in southern pine plantations [15]. Hardwood management is common in production forests of the Appalachian Mountains and portions of the Piedmont region in the SE, and these forests are managed with a wide range of silvicultural options, including selection harvests or clearcutting to promote the natural regeneration of high quality species, including oaks (Quercus spp.) [37,39,40]. Shearing of stumps, bedding or other mechanical site preparation techniques remain a critical regional difference (Figure 1) in regeneration practices that could affect organisms, such as salamanders, that use CWD, leaf litter and upper portions of the soil profile, but more investigation is needed $[25,28,41]$.

Figure 1. Habitat conditions for plethodontid salamanders is influenced by silvicultural regimes and relative management intensity, which influences proximate habitat characteristics, leading to a range of predicted suitability. Adapted from Ramovs and Roberts (2003) [42]. CWD, coarse woody debris.

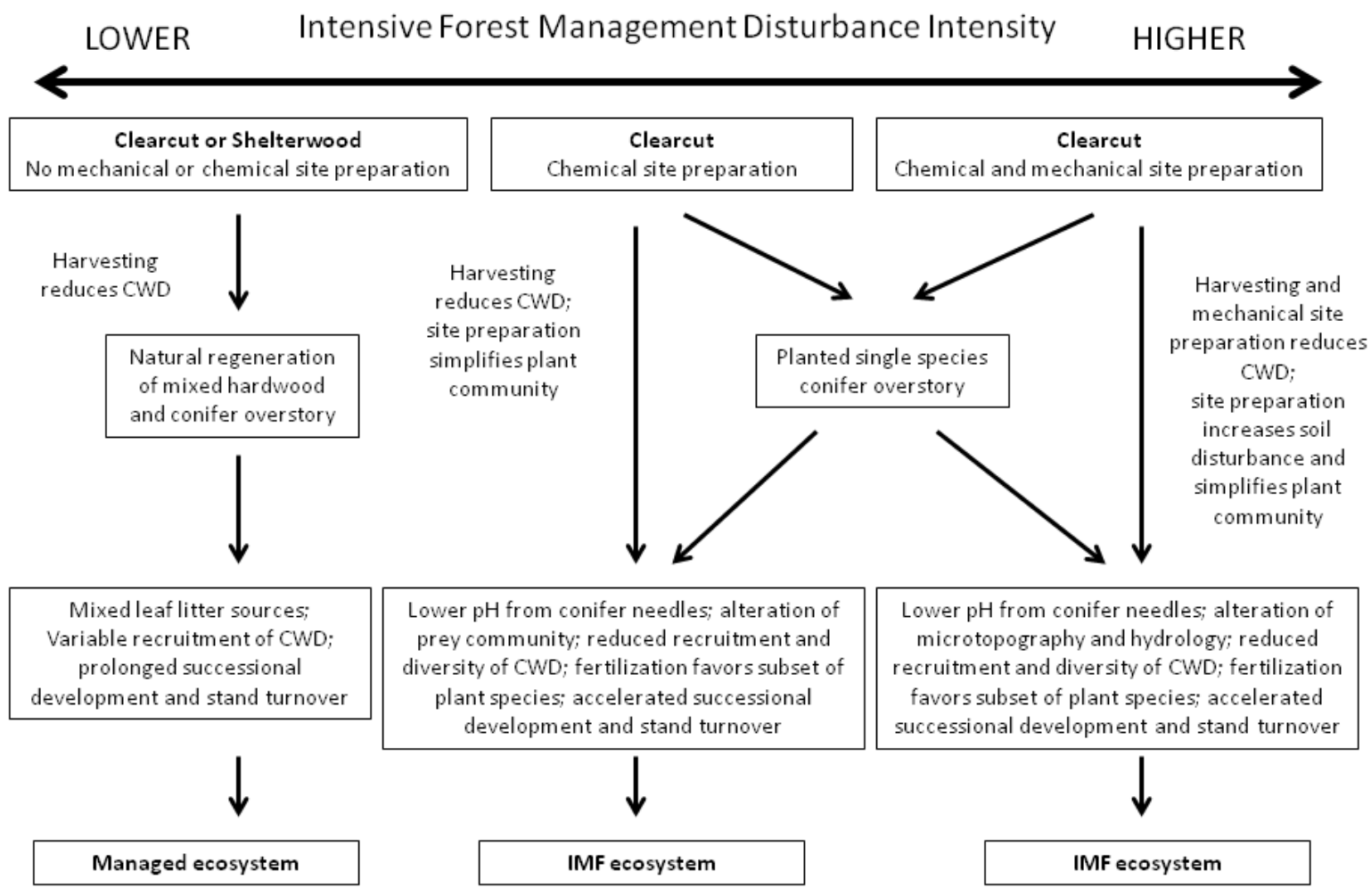

\section{HIGHER Predicted Suitability for Plethodontid Salamanders LOWER}

Across both regions, the application of forestry and water quality best management practices (BMPs; [43]), state forest practice rules (e.g., stipulating riparian/upland set-asides and green-tree retention) and requirements for sustainable forestry certification (spatial and temporal distributions of coarse woody debris, a broad distribution of age classes) create heterogeneity at the stand scale [44-46]. However, uniform application of BMPs, voluntary certification guidelines, regulations, including limits 
to harvest unit size and adjacency requirements (time or structural characteristics required before neighboring stands can be harvested), and uniform operational prescriptions across IMF ownerships likely contribute to homogeneity at the landscape scale, regardless of region [47]. Available information is insufficient to determine how organisms respond to novel stand and landscape conditions created by the interactions of operational practices and forest practice regulations. Further, whether and/or how the presence of unmanaged forest within the same landscapes as IMF mediates organismal responses, including those of plethodontid salamanders, merits research attention [48].

Ownership patterns also create substantial variation, both across and within the PNW and SE. In the PNW, private, state and federal ownerships are distributed as both large, consolidated holdings and dispersed parcels. In addition, historic allocations from public to private ownership resulted in "checker-boarding" patterns (where every other square mile (259 ha) parcel is owned by a private or public entity) [48]. In the SE, nearly $86 \%$ of forest is privately owned and distributed broadly across parcel sizes from a few-ha family woodlot to millions of ha managed as a timberland real estate investment trust [37]. In either case, multiple ownerships, characterized by different economic and environmental objectives, can result in highly variable stand conditions and fragmented landscapes [49]. Across ownerships, IMF ecosystems are less likely to occur along a gradient of management intensity, but are in opposition to forests that no longer are subject to any form of management (except the suppression of natural disturbance agents, such as fire and insect outbreaks) [50]. Finally, the potential for rapid conversion of large private parcels to other land uses represents an underappreciated, growing challenge to both conservation of biological diversity and sustainable provisioning of commodities [6,51].

The ability of IMF ecosystems to sustain levels of biological diversity compared to unmanaged forests, whereas providing goods for human consumption, is questioned regularly [11,14,52]. Two emerging concepts, emulation of natural disturbance (END; [53]) prescriptions and land sharing vs. land sparing allocations $[54,55]$, are potentially profitable means to advance current debates about IMF ecosystems. Prescriptions based on END conserve ecosystem structure and function by encompassing historical ranges of variation in ecosystem conditions across multiple spatial and temporal scales [53]. Emulation of natural disturbance is designed to increase resiliency of ecosystems against future natural and anthropogenic disturbances [56]. To do so, prescriptions aim to capture similar structural and functional diversity compared to what inevitably occurs after natural disturbances [16,17,57]. Land sharing vs. land sparing allocations emerged from debates about sustainable production of food commodities [54]. Land sparing separates conservation and production land (although both types can occur in the same landscape, [58]), as intensive management precludes the need to produce commodities on all of the land base. Under a land-sharing scenario, low-intensity production occurs across a larger percentage of the landscape (e.g., [59]). We note that IMF ecosystems in the PNW, as shaped by current operational practices and regulatory requirements, and by sharing regional landscapes with publicly owned, unmanaged forest ecosystems, resemble a land-sparing allocation [49]. Finally, although embedding END prescriptions within a land-sharing framework is appealing from a conservation perspective, we are unaware of any studies that examined economic consequences of this strategy for IMF ecosystems. That is, how much does net area under management increase to meet current and future demand for commodities, and is a significant increase in biological diversity achieved [60]? This broad variation in design and composition of IMF landscapes presents a challenge to understanding the effects 
of habitat alteration on biological diversity. An alternative and/or complementary approach to guide sustainable forest management is to select indicator species for a greater range of organisms or structural conditions $[61,62]$. However, as we note in the next section, this approach has both positive and negative aspects that require careful consideration.

\section{Salamanders as Barometers of Forest Condition}

Plethodontid salamanders have numerous ecological, physiological and morphological characteristics linking them to a "slow life" in forest ecosystems. Many long-lived species do not reach reproductive maturity for several years and have low reproductive rates that limit population growth. For example, eastern red-backed salamanders (Plethodon cinereus), a common and well-studied species in eastern North America, may not reach reproductive maturity until 3-4 years old, and females only produce about seven eggs biennially [29,63,64]. All plethodontids lack lungs and, as adults, respire cutaneously [65]. Cool, moist microclimates facilitate gas exchange across the skin of salamanders and, because they are ectotherms, reduce metabolic costs and affect physiological processes from digestion to growth [66-68]. Increased metabolic costs resulting from warmer and potentially dryer forests following forest harvesting may be a key contributor to observed declines in salamander abundances and changes to demography [69]. However, quantification of actual energetic costs of salamanders in harvested and unharvested units has not been conducted [25]. Approximately 70\% of North American salamanders lay terrestrial eggs that develop directly into adults without an aquatic larval stage, a reproductive strategy that also requires humid and cool conditions for egg survival. Additionally, stream-associated salamanders with aquatic larvae need suitable microclimatic conditions to support dispersal of juveniles post-metamorphosis and of adults into upland habitats [70,71]. Consequently, the slow lives of salamanders likely necessitate decades-long recovery periods for population declines caused by anthropogenic habitat alterations, such as forest harvesting [29,72,73].

In addition to life history requirements tied to narrow microclimate conditions in forest ecosystems, plethodontid salamanders exemplify other characteristics of potential indicator species [24]. Plethodontid salamanders are sensitive to environmental changes, including acidification [74] and heavy metals contamination [75,76], and can transfer contaminants to their young [77]. They are often locally abundant and relatively simple and inexpensive to sample, conferring statistical advantages for subsequent analyses [78], but see [79]. Further, energetic efficiency is a paramount attribute of salamanders, as plethodontids convert a greater proportion of assimilated energy into biomass than other taxa, including other herpetofauna [21]. This biomass, or stored energy, is available to numerous predators of these small, euryphagic consumers of invertebrates and contributes to energy flow within an ecosystem. As such, salamanders have been termed keystone species of the forest floor and lauded for their ability to regulate invertebrate prey, litter decomposition rates and even contribute to carbon sequestration $[80,81]$. However, examination of this body of work suggests substantial variability exists in response metrics among salamander, invertebrate and overstory tree (litter source) species [24,82-84]. Whereas researchers have documented top-down regulation of some invertebrate taxa and/or leaf litter decomposition, results are inconsistent across invertebrate guilds and, in some cases, experimental designs (i.e., field plots, semi-natural mesocosms, laboratory microcosm) [80-82,85]. In other experiments, salamanders did not influence ecosystem functions or 
potential prey, further complicating any broader understanding of ecological roles of salamanders in the complex detrital food web [83].

Due to these attributes and observed declines in abundance associated with many silvicultural systems, researchers and managers have cited salamanders as a barometer of forest condition (Figure 2), with an abundant and diverse salamander community taken as evidence of a resistant, intact and healthy ecosystem [19]. However, prior to selection, indicator species should be tested rigorously to ensure consistent relationships with other taxa, disturbances or responses of interest at the appropriate spatial and temporal scales $[61,86,87]$. Little research exists that has compared characteristics of plethodontid salamanders to other forest-dependent species or evaluated empirically whether population status of these taxa provides an acceptable surrogate for the complex ecological processes that they are presumed to represent $[61,88,89]$. For example, in an experiment in Appalachian hardwood forest, the herbaceous plant community responded to a gradient of overstory removal harvests as expected, with greater compositional change with greater treatment intensity [90]. On the same experimental research sites, compositional stability of plethodontid salamanders varied through time post-harvest and across treatments, suggesting a lack of cross-taxa congruence between plants and salamanders (Homyack, J.A. [91]). Thus, without close examination of relationships between these groups, one could have interpreted erroneously that a pattern existed in salamander responses to a broader context, including herbaceous plants. Finally, despite their abundance, terrestrial salamanders often have low or variable detection and recapture rates, as well as small body sizes, factors that complicate tracking individuals and quantifying population responses accurately [79,92-95].

Figure 2. Characteristics of plethodontid salamanders make them both desirable and problematic for serving as barometers of forest change and ecosystem health in intensively-managed forest (IMF) ecosystems.

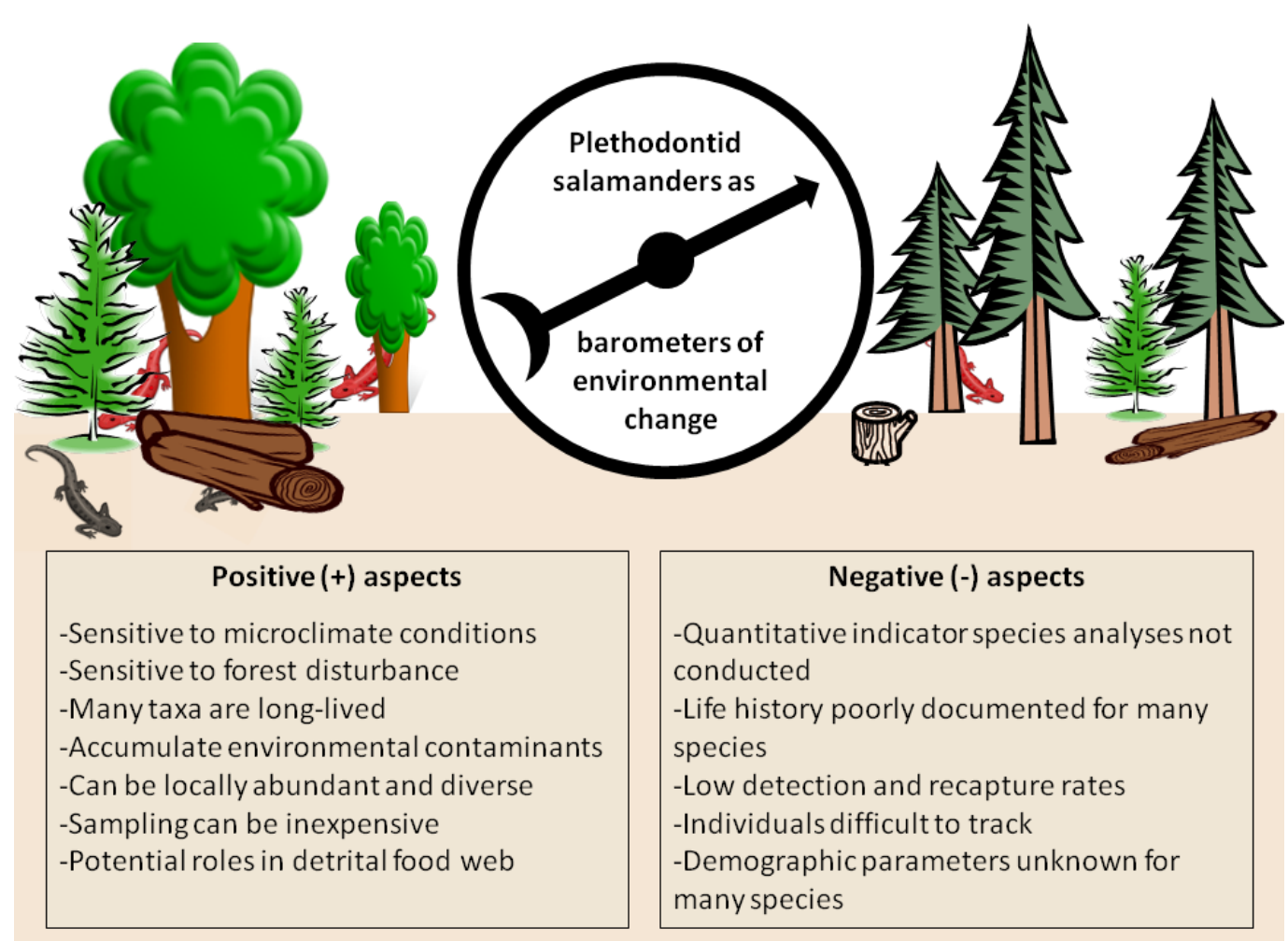




\section{Case Studies of Salamanders in Managed Forests}

Often, observed relationships between salamanders and forest structure from a specific research study have been expanded across species, ecosystems and forest management regimes without detailed examinations of mechanisms or meta-analyses to detect broader patterns (but see [27,28]). For example, coarse woody debris is undoubtedly a critical element of forests for numerous terrestrial salamanders [96]. Logs, stumps and root masses on the forest floor provide a means of subterranean entry, refugia from inhospitable microclimates, habitat and foraging surfaces for invertebrate prey, access to mates and habitat conditions for brooding eggs, and many species establish territories under woody debris [20]. Intensively-managed forest ecosystems may provide lower volumes, piece sizes and decay classes of CWD, as large, well-decayed debris is often redistributed or rarer after forest harvest and tends to decline after multiple rotations [28,97-99]. Also, many management guidelines recommend adequate recruitment and retention of woody debris in managed forests to maintain or enhance salamander communities [28,100]. Emerging biofuel markets that rely on woody debris or formerly nonmerchantable material gleaned following harvests may reduce woody debris below thresholds required by salamanders or other wildlife [96,101]. Thus, documenting variability in existence and strength of relationships between salamanders and CWD is necessary for developing an understanding of increased intensity of forest management.

To describe potential variation in the strength and direction of the relationships between plethodontid salamanders and CWD in IMF ecosystems, we developed two case studies. First, we illustrate relationships between plethodontid salamanders and CWD in intensively-managed Douglas-fir forests of the Pacific Northwest. Second, we modeled microhabitat relationships and examined patterns of substrate use by plethodontid salamanders in mixed-hardwood forests in Virginia and West Virginia. Although the Appalachian hardwood forest is extraneous to our prior discussion of southern pine plantations, much of our current knowledge regarding plethodontid salamanders and CWD is from this region, and the example is appropriate for illustrating variability.

\subsection{Douglas-Fir Regeneration and Plethodontid Salamanders in Cascades Forest}

We studied Oregon slender (Batrachoseps wrighti) and ensatina (Ensatina eschscholtzii) salamanders at 66 forested harvest units (i.e., stands) in the Cascade Range, Oregon, USA. The harvest unit age ranged from 35 to 90 (average $=60 ; \mathrm{SD}=8$ ) years and from 20 to 183 ha (average $=79 ; \mathrm{SD}=33$ ). Harvest units occurred in one of two study blocks: Clackamas (Clackamas County, OR, USA) or Snow Peak (Linn County, OR, USA). All units were regenerated from previous clearcut harvests. We selected harvest units randomly for inclusion within a long-term experimental study of salamander responses to contemporary management prescriptions.

To understand how Oregon slender and ensatina salamanders responded to variation in the amount of CWD, we estimated both occupancy and abundance with hierarchical models [102,103]. Within each harvest unit, we sampled seven $81-\mathrm{m}^{2}(9 \times 9 \mathrm{~m})$ plots in 2013-2014. Each 81- $\mathrm{m}^{2}$ plot was selected randomly and sampled over three consecutive 10-min intervals in a single day (sampling occurred between 08:00 and 16:00 and from April to June). Spatial and temporal replication was necessary to estimate and incorporate detection into estimates of occupancy and abundance [104]. Observers 
employed a "light touch" methodology in which all surface objects, including leaf litter and moss blankets on logs, were turned over to observe salamanders. We followed a "removal" sampling protocol in which sampling stopped once both species were observed in a plot [105]. During sampling, observers quantified the amount of CWD (all $\operatorname{logs}>25 \mathrm{~cm} \mathrm{DBH}$ (small end) and $>1 \mathrm{~m}$ in length). To estimate occupancy and abundance, we fit hierarchical models within a Bayesian framework [106]. We used a multi-scale model that allowed us to estimate occupancy at both the harvest unit and plot levels [102,107]. For abundance, we fit a model presented by Royle and Nichols [103]. We allowed occupancy and abundance to vary with block and amount of CWD in an 81- $\mathrm{m}^{2}$ plot and detection probability to vary with sampling date.

We detected 149 and 133 Oregon slender and 64 and 83 ensatina salamanders in 2013 and 2014, respectively (60 harvest units in 2013 and 55 harvest units in 2014). Oregon slender salamanders were detected in 53/420 (34\%) plots and 101/378 (27\%) plots in 2013 and 2014, respectively; ensatina salamanders were detected in 144/420 (13\%) plots and 73/378 (19\%) plots in 2013 and 2014, respectively. Abundance of Oregon slender salamanders was strongly associated with amount of CWD (Figure 3). For Oregon slender salamanders, average occupancy was greater at Clackamas than Snow Peak in both 2013 and 2014 (Table 1). For ensatina salamanders, we did not find evidence of an association between abundance and CWD (Figure 3). Further, average occupancy was greater at Snow Peak than Clackamas in both 2013 and 2014. Harvest unit occupancy was $\sim 1$ for both species.

Figure 3. Association between abundance of Oregon slender (Batrachoseps wrighti) (OSS) and ensatina (Ensatina eschscholtzii) (ENES) salamanders and downed wood, Cascade Range, OR, USA, 2013-2014. All logs $>25 \mathrm{~cm}$ DBH (small end) and $>1 \mathrm{~m}$ in length were included in coarse woody debris (CWD) counts. CRI = credibility interval.

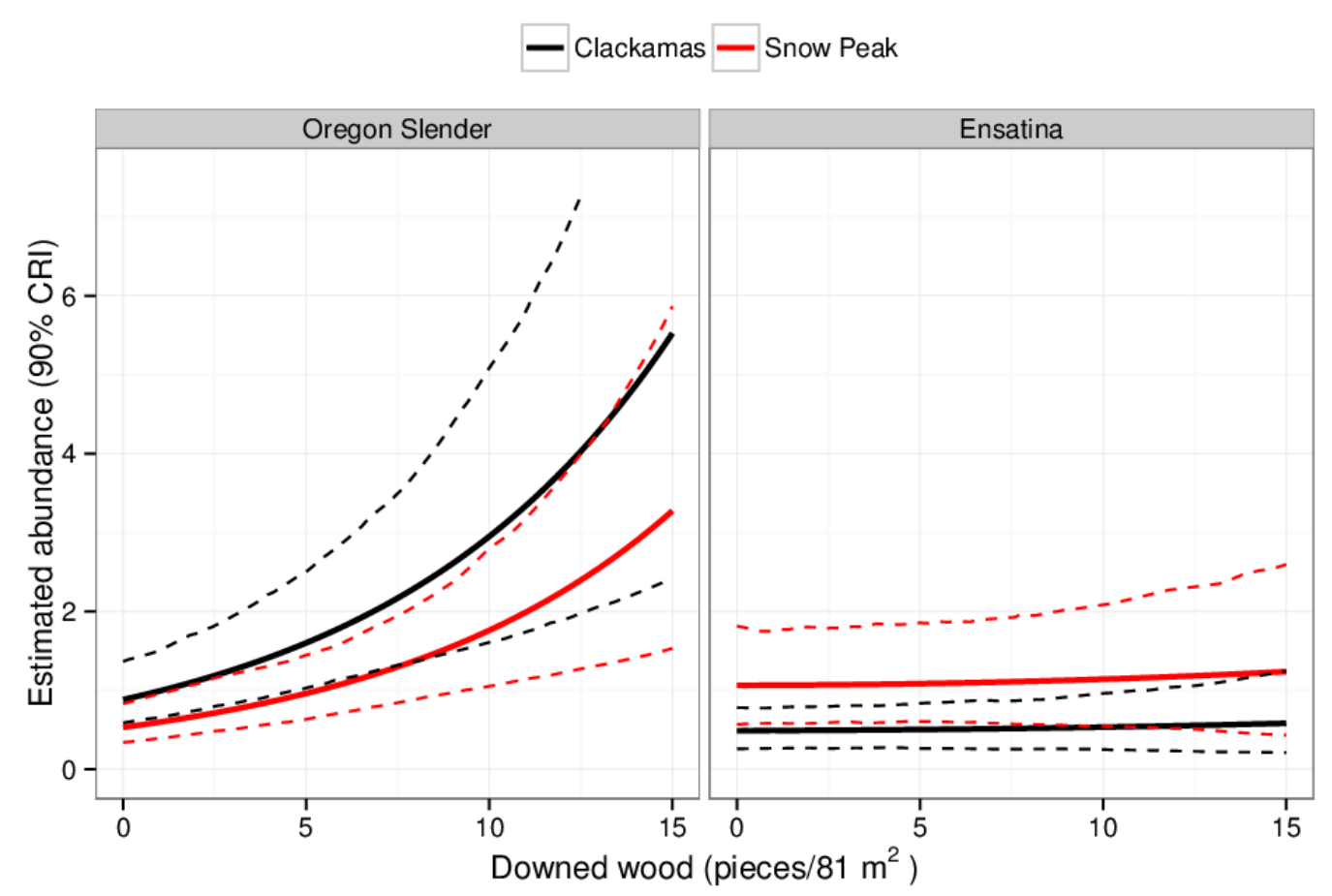


Table 1. Occupancy and abundance of Oregon slender (Batrachoseps wrighti) and ensatina (Ensatina eschscholtzii) salamanders by study block and year at average amounts of CWD (Clackamas: 2.4, $\mathrm{SD}=2.2$, range $=0-10$; Snow Peak: 3.6, $\mathrm{SD}=2.7$, range $=0-15$ ), Cascade Range, OR, USA, 2013-2014. All logs $>25 \mathrm{~cm} \mathrm{DBH}$ (small end) and $>1 \mathrm{~m}$ in length were included in CWD counts.

\begin{tabular}{ccccccc}
\hline Species & Block & Year & $\begin{array}{c}\text { Occupancy } \\
\text { Estimate }\end{array}$ & $\mathbf{9 5 \%}$ CI & $\begin{array}{c}\text { Abundance } \\
\text { Estimate }\end{array}$ & 95\% CI \\
\hline \multirow{5}{*}{ Oregon slender } & Snow Peak & 2013 & 0.59 & $0.45,0.75$ & 0.91 & $0.60,1.38$ \\
& Clackamas & 2013 & 0.76 & $0.63,0.90$ & 1.5 & $0.99,2.32$ \\
& Snow Peak & 2014 & 0.45 & $0.33,0.63$ & 0.62 & $0.41,0.99$ \\
& Clackamas & 2014 & 0.63 & $0.48,0.80$ & 1.03 & $0.66,1.62$ \\
& Snow Peak & 2013 & 0.61 & $0.41,0.82$ & 1.0 & $0.52,1.7$ \\
& Clackamas & 2013 & 0.36 & $0.21,0.53$ & 0.46 & $0.24,0.76$ \\
& Snow Peak & 2014 & 0.66 & $0.47,0.86$ & 1.15 & $0.64,1.95$ \\
& Clackamas & 2014 & 0.25 & $0.34,0.56$ & 0.53 & $0.28,0.83$ \\
\hline
\end{tabular}

We found that Oregon slender and ensatina salamanders were common in the second growth forest stands we sampled. These results suggest that both species either persisted in units following harvest and/or were able to recolonize units as they regenerated over time. However, we did not find an association between CWD and ensatina responses. This result was not surprising, given the species has a broad geographic distribution and occurs in a wide range of habitat types [108]. In contrast, Oregon slender salamander responses were associated strongly with the amount of CWD. General observations suggest this species uses CWD for both foraging and rearing young [108]. Additionally, most of its geographic distribution occurs in forests of the western Cascade Range that contain substantial amounts of CWD and standing biomass [109]. However, our results suggest that within these forests, population size is positively associated with the amount of CWD. Therefore, providing adequate amounts of CWD may be required to support persistence of Oregon slender salamanders in IMF ecosystems, but we have not identified a minimum threshold. Finally, the inter-specific variation in this case study exemplifies concerns about the dogmatic application of similar prescriptions to provide suitable habitat for all plethodontid species.

\subsection{Relationships of Plethodontid Salamanders with Woody Debris in Appalachian Forest}

We studied plethodontid salamanders and associations with CWD in managed forests across six study sites located in mixed hardwood forest in the Jefferson National Forest, Virginia $(n=4)$, and private, industrial forest, West Virginia, USA $(n=2)$ [110]. Silvicultural prescriptions were applied randomly to seven, 2-ha treatment plots at each site during 1994-1998. In order of increasing overstory removal, prescriptions included a control, a mid-story removal with herbicide, group selection, high-leave shelterwood, leave-tree harvest, commercial clearcut and silvicultural clearcut [29]. Treatments represented a gradient of typical silvicultural options for oak regeneration.

To understand whether CWD or other micro- or macro-scale characteristics predicted relative abundance of plethodontid salamanders across spatial scales, we quantified the relative abundance of plethodontid salamanders, measured a suite of habitat characteristics, developed a priori candidate 
models representing biological or environmental hypotheses relating salamanders to forest structure and evaluated relative evidence for each model with an information-theoretic approach [110]. First, we quantified habitat characteristics and relative abundances of plethodontid salamanders on sampling grids of $2 \times 15-\mathrm{m}$ transects established within each treatment plot at each study site. We quantified the relative abundances of surface-active salamanders with searches of one randomly-selected transect per treatment plot/site during warm $\left(>4{ }^{\circ} \mathrm{C}\right)$, rainy (leaf litter remained moist) nights, April-August, 2007. Observers crawled along transects, hand-captured salamanders and marked the point of capture with an individually-numbered pin-flag. We also recorded the substrate (e.g., log, stump, leaf litter) where salamanders were observed and identified captures to species.

After salamander sampling, we quantified habitat characteristics at the: (1) treatment plot scale; (2) scale of the entire $30-\mathrm{m}^{2}$ transect; or (3) a smaller, sub-transect $(2 \mathrm{~m} \times 5 \mathrm{~m})$ scale of $10 \mathrm{~m}^{2}$ for all sampled transects. We quantified correlates or predictors of salamander abundance, including basal area, leaf litter depth, number, volume and decomposition class of CWD [111], densities of trees and shrubs and the percent cover of leaf litter, vegetation, rocks, moss, bare soil and CWD, all of which are altered by forest harvesting. Our candidate model set contained habitat covariates that described forest structure related to large-scale habitat conditions (basal area), foraging, refugia and nest sites, retention of ground-level moisture and combinations of the three factors, in addition to a global model. We used simple linear regression and applied the candidate set of models to data collected at the $30-\mathrm{m}^{2}$ transect and a randomly selected $10-\mathrm{m}^{2}$ nested sub-transect and evaluated the balance between goodness-of-fit and statistical parsimony using AIC, model weights $\left(w_{\mathrm{i}}\right)$ and $R^{2}$ values. During 2006-2008, we qualitatively evaluated the proportion of salamander captures on CWD and compared them to other substrate types and across species and evaluated whether the plots were harvested (control and herbicide $v s$. other treatments).

In 2007, we sampled 155 transects and captured 653 salamanders of 10 species (P. glutinosus and $P$. cylindraceus were combined into slimy salamanders), with 0-22 salamanders/transect and 0-10 salamanders/sub-transect. Salamander counts were dominated by eastern red-backed salamanders, Allegheny mountain dusky salamanders (Desmognathus ochrophaeus), slimy salamanders and ravine salamanders ( $P$. richmondi). Abundances of plethodontid salamanders at the scale of the $30-\mathrm{m}^{2}$ transect were best $\left(\triangle \mathrm{AIC}=0, w_{i}=0.58\right.$; Table 2$)$ described by a positive association with basal area and herbaceous cover and a negative association with litter depth. However, some evidence existed for a positive relationship between salamanders and basal area at the plot scale $\left(\triangle \mathrm{AIC}=1.40, w_{i}=0.29\right)$. At the sub-transect scale, the model describing basal area at the plot scale had the greatest model weight $\left(\triangle \mathrm{AIC}=0, w_{i}=0.59\right)$, but models describing overhead canopy conditions $\left(\Delta \mathrm{AIC}=1.98, w_{i}=0.22\right)$ and overhead canopy conditions and foraging habitat $\left(\triangle \mathrm{AIC}=2.38, w_{i}=0.18\right)$ received support. Secondly, across 2480 salamanders captured across three years, most (75\%) surface-active salamanders were captured on leaf litter. The proportion of salamanders captured on leaf litter varied from $51 \%$ to $86 \%$ across species (Table 3). Salamanders found on coarse or fine woody debris (FWD) accounted for 10\% of total captures and $8 \%-22 \%$ by species. Within a species or across all species, harvest history appeared to have relatively small effects on use of CWD or FWD, except for the small sample of Wehrle's salamanders (P. wehrlei). Wehrle's salamanders in unharvested plots primarily were captured on leaf litter $(59 \%)$ or trees and saplings $(26 \%)$, but those captured on harvested plots were mostly on CWD/FWD (44\%) or leaf litter (39\%). 
Table 2. Parameter estimates and strength of evidence (AIC) from linear regression relating relative abundances of plethodontid salamanders from surface counts to forest structural characteristics across spatial scales. We present data from models with $\Delta \mathrm{AIC}<2.0$ at both the 30 - and $10-\mathrm{m}^{2}$ scale. Abundances of salamanders and habitat characteristics were quantified in mixed-oak forest on six study sites in southwestern VA and north-central WV, USA, April-August, 2007.

\begin{tabular}{|c|c|c|c|c|c|c|}
\hline Model & $\triangle \mathrm{AIC}$ & Model Weight $\left(w_{i}\right)$ & $R^{2}$ & $\beta$ & SE & Direction \\
\hline $\begin{array}{l}\text { Overhead Canopy Conditions } \\
\text { and Foraging }\left(30-\mathrm{m}^{2} \mathrm{scale}\right)\end{array}$ & 0 & 0.58 & 0.29 & & & \\
\hline Intercept & & & & 2.724 & 1.039 & \\
\hline Basal Area & & & & 0.146 & 0.030 & + \\
\hline Understory Density & & & & 0.003 & 0.014 & + \\
\hline Leaf Litter Depth & & & & -0.410 & 0.147 & - \\
\hline Percent Herbaceous Cover & & & & 0.061 & 0.029 & + \\
\hline $\begin{array}{l}\text { Large-Scale Habitat Conditions } \\
\qquad\left(30-\mathrm{m}^{2} \text { scale }\right)\end{array}$ & 1.40 & 0.29 & 0.20 & & & \\
\hline Intercept & & & & 1.435 & 0.536 & \\
\hline Basal Area & & & & 0.158 & 0.025 & + \\
\hline $\begin{array}{l}\text { Large-Scale Habitat Conditions } \\
\qquad\left(10-\mathrm{m}^{2} \mathrm{scale}\right)\end{array}$ & 0.00 & 0.59 & 0.15 & & & \\
\hline Intercept & & & & 0.421 & 0.246 & \\
\hline Basal Area & & & & 0.059 & 0.011 & + \\
\hline $\begin{array}{l}\text { Overhead Canopy Conditions } \\
\qquad\left(10-\mathrm{m}^{2} \text { scale }\right)\end{array}$ & 1.98 & 0.22 & 0.15 & & & \\
\hline Intercept & & & & 0.371 & 0.359 & \\
\hline Basal Area & & & & 0.060 & 0.013 & + \\
\hline Understory Density & & & & 0.003 & 0.015 & + \\
\hline
\end{tabular}

For direction, + refers to a positive association and - refers to a negative association with the variable.

Similar to recent work in Missouri hardwood forest [112], our results suggest that foraging or active salamanders likely did not solely rely on CWD during wet conditions in our study area at night. Our modeling of salamander abundance indicated that broad-scale metrics describing overstory conditions had greater predictive power than local-scale metrics describing CWD or other ground-level characteristics. Further, across 2500 captures of salamanders (dominated by eastern red-backed salamanders) during night sampling, most were observed on leaf litter rather than available CWD. Observed relationships generally were consistent across species regardless of recent ( $<14$ years) harvesting activity, but Wehrle's salamanders may have been more reliant on CWD in harvested plots. Low sample sizes preclude strong inferences, but suggest avenues for future empirical research to understand inter-specific variability in associations with CWD or other microhabitat characteristics of suspected biological importance. 
Table 3. Percentage of salamander captures by substrate type when captured during night-time area constrained searches of plots in experimentally treated Appalachian hardwood forest, VA and WV, USA, 2006-2008. No harvest treatments included untreated control plots and a mid-story herbicide release plot. Harvest treatments included a group selection, shelterwood harvest, leave tree, commercial clearcut and a silvicultural clearcut.

\begin{tabular}{|c|c|c|c|c|c|c|c|c|c|}
\hline Category & Species & CWD/FWD ${ }^{\mathrm{a}}$ & Leaf Litter & Tree/Sapling & Herbaceous & Rock & Bare Ground & Other & Number of Captures \\
\hline All Treatments & Total Salamanders & 10.0 & 75.0 & 6.1 & 1.3 & 2.3 & 0.8 & 4.5 & 2480 \\
\hline No Harvest Treatments & & 7.5 & 77.0 & 6.3 & 1.7 & 2.3 & 0.9 & 4.4 & 1311 \\
\hline Harvest Treatments & & 12.8 & 72.7 & 5.9 & 0.9 & 2.4 & 0.8 & 4.5 & 1169 \\
\hline All Treatments & Plethodon cinereus & 7.7 & 75.9 & 6.7 & 1.5 & 3.2 & 1.5 & 3.5 & 1107 \\
\hline No Harvest Treatments & & 6.3 & 76.9 & 6.3 & 1.9 & 3.7 & 1.8 & 3.0 & 567 \\
\hline Harvest Treatments & & 9.1 & 74.8 & 7.0 & 1.1 & 2.6 & 1.3 & 4.1 & 540 \\
\hline All Treatments & Desmognathus spp. & 9.4 & 75.5 & 7.0 & 1.7 & 0.2 & 0.2 & 6.1 & 641 \\
\hline No Harvest Treatments & & 7.3 & 77.3 & 7.6 & 1.7 & 0.0 & 0.0 & 6.1 & 423 \\
\hline Harvest Treatments & & 13.3 & 72.0 & 6.0 & 1.8 & 0.5 & 0.5 & 6.0 & 218 \\
\hline All Treatments & P. glutinosus complex & 16.8 & 69.3 & 3.2 & 0.4 & 4.1 & 0.6 & 5.4 & 463 \\
\hline No Harvest Treatments & & 13.2 & 69.5 & 3.6 & 0.6 & 4.2 & 1.2 & 7.8 & 167 \\
\hline Harvest Treatments & & 13.3 & 72.0 & 6.0 & 1.8 & 0.5 & 0.5 & 6.0 & 218 \\
\hline All Treatments & P. richmondi & 5.2 & 86.0 & 4.1 & 1.6 & 0.0 & 0.0 & 3.1 & 193 \\
\hline No Harvest Treatments & & 5.4 & 89.3 & 0.9 & 2.7 & 0.0 & 0.0 & 1.8 & 112 \\
\hline Harvest Treatments & & 4.9 & 81.5 & 8.6 & 0.0 & 0.0 & 0.0 & 4.9 & 81 \\
\hline All Treatments & P. wehrlei & 22.2 & 51.1 & 17.8 & 0.0 & 6.7 & 0.0 & 2.2 & 45 \\
\hline No Harvest Treatments & & 7.4 & 59.3 & 25.9 & 0.0 & 7.4 & 0.0 & 0.0 & 27 \\
\hline Harvest Treatments & & 44.4 & 38.9 & 5.6 & 0.0 & 5.6 & 0.0 & 5.6 & 18 \\
\hline
\end{tabular}

${ }^{\mathrm{a}} \mathrm{CWD} / \mathrm{FWD}$ refers to coarse and fine woody debris, including logs, stumps, root masses and sticks. 


\section{Conclusions}

\subsection{Beyond CWD}

The direct linkages among physiology and reproduction of plethodontid salamanders and CWD and research linking the presence of salamanders to logs, stumps and root masses has led to a simplistic view of habitat requirements for this family. Efforts to retain persistent populations of plethodontid salamanders on IMF ecosystems should move beyond a default focus on CWD to integrate documented variability among salamander species, regions, topographical features and ecosystems to maximize conservation benefits for the greatest number of species. DeMaynadier and Hunter [28] summarized published relationships between plethodontid salamanders and microhabitat characteristics, and associations with rocks, litter depth, understory vegetation, canopy closure and moisture often were more frequently positively associated with salamanders than CWD. As the previous case studies and the work of DeMaynadier and Hunter [28] illustrate, a universal relationship between downed woody material and salamanders does not exist, but rather, a myriad of factors impart significant variation to relationships between plethodontids and their habitat. Similarly, other herpetofaunal species have exhibited variable relationships with experimental manipulations of woody debris [25,113-115], but manipulative research from the PNW is notably lacking.

Further, many North American plethodontid salamanders are habitat specialists that rely on features other than CWD to meet life history requirements. For example, green salamanders (Aneides aneides) are associated with boulders, rock crevices or tall deciduous trees; Red Hills salamanders (Phaeognathus hubrichti) occur only on steep hardwood ravines of a few select geologic formations; and talus slopes formed from lava flows are primary habitat for Larch Mountain salamanders (Plethodon larselli). As we have described, IMF ecosystems present different conservation challenges than other landscapes, and developing management recommendations without recognizing needs of habitat specialists may not minimize effects of harvesting and regeneration activities for many species, including those of immediate conservation concern. Thus, integrating a combination of filter grains, from coarse- to fine-scale approaches to conservation, will be necessary for conservation of salamanders in IMF ecosystems [116,117].

\subsection{Opportunities for Future Research}

Given the need for IMF ecosystems to provide ecosystem services in conjunction with sustainable production of commodities, an increase in understanding of mechanisms behind population trends of salamanders in production forests is integral for mitigating negative effects where and when they occur. We encourage additional research in IMF ecosystems to document mechanisms of population change, such as whether reduced reproduction and abundance occur from proximate (e.g., prey abundance) or ultimate (e.g., $\mathrm{pH}$, moisture) factors after harvest and regeneration [28]. When developing future monitoring and research programs, practitioners and scientists could consider experimental designs and best practices that meet clearly-defined research objectives. For terrestrial salamanders in IMF ecosystems, these practices could include incorporating methods to estimate detection probabilities to reduce bias, pre- and post-treatment estimates of abundance or occupancy, long-term data collection to capture population and demographic trends over a complete turnover of these relatively long-lived 
species to capture variability across anticipated stand rotation lengths and designing studies to examine potential impacts of silvicultural activities at micro- to landscape scales [96,118,119]. Meta-analyses (e.g., [27]) that examine inter-specific, regional and spatio-temporal differences in population responses to manipulation of habitat characteristics in IMF ecosystems are critical to drawing strong inferences about the broader impacts of forest management on plethodontid salamanders.

Likewise, describing individual-, population- and community-level responses of salamanders to experimentally manipulated habitat features in IMF ecosystems will develop a mechanistic understanding of how forest management influences habitat quality [120]. Researchers could integrate salamander responses with quantifying changes to environmental metrics, such as soil moisture, micro- and macro-topography or CWD, as much remains to be learned. For example, altered abundance, piece sizes and decay classes of CWD occur after most types of forest harvesting or other silvicultural activities [96,121-123], but little is known about CWD and FWD dynamics across IMF ecosystems or silvicultural regimes [124,125]. Finally, many plethodontid salamanders lack basic population, demographic or natural history information, limiting the use of models to estimate population growth rates, to characterize resistance and resiliency to environmental perturbations and to evaluate rigorously their use as indicator species.

As with agriculture [126], appropriately managed intensification of forest management can meet human demands and conserve biological diversity. Creative, collaborative relationships among forest industry, state and federal agencies, universities and non-profit organizations are necessary to navigate the difficulties of securing long-term funds and access for monitoring and research of plethodontid salamanders [118]. Successful research programs will identify the types and amounts of forest structural attributes that promote persistence and re-colonization of unoccupied sites through rotations. However, these labors will only be realized when knowledge gains are translated and implemented as management activities that promote population persistence of target species while maintaining intensive forestry as a profitable and necessary enterprise in multi-ownership geographies.

\section{Acknowledgments}

We thank Thomas Gorman, Darren Miller, and two anonymous reviewers for improving reviewing earlier drafts of this manuscript. The case study in eastern forest was supported by a USDA National Research Initiative grant to Carola Haas et al. (2005-35101-15363), and an AdvanceVT Doctoral Fellowship provided to Jessica Homyack (SBE-0244916).

\section{Author Contributions}

Both authors contributed to the development and writing of this paper.

\section{Conflicts of Interest}

The authors declare no conflict of interest. 


\section{References}

1. Pan, Y.; Birdsey, R.A.; Phillips, O.L.; Jackson, R.B. The structure, distribution, and biomass of the world's forests. Annu. Rev. Ecol. Evol. Syst. 2013, 44, 593-622.

2. State of the World's Forests 2012; Food and Agriculture Organization of the United Nations: Rome, Italy, 2012.

3. Berlik, M.M.; Kittredge, D.B.; Foster, D.R. The illusion of preservation: A global environmental argument for the local production of natural resources. J. Biogeogr. 2002, 29, 1557-1568.

4. Abernethy, K.A.; Coad, L.; Taylor, G.; Lee, M.E.; Maisels, F. Extent and ecological consequences of hunting in Central African rainforests in the twenty-first century. Philos. Trans. R. Soc. B Biol. Sci. 2013, 368, doi:10.1098/rstb.2012.0303.

5. Berger, A.L.; Palik, B.; D'Amato, A.W.; Fraver, S.; Bradford, J.B.; Nislow, K.; King, D.; Brooks, R.T. Ecological impacts of energy-wood harvests: Lessons from whole-tree harvesting and natural disturbance. J. For. 2013, 111, 139-153.

6. Stein, S.M.; McRoberts, R.E.; Alig, R.J.; Nelson, M.D.; Theobald, D.M.; Eley, M.; Dechter, M.; Carr, M.A. Forests on the Edge: Housing Development on America's Private Forests; Gen. Tech. Rep. PNW-636; Department of Agriculture, Forest Service, Pacific Northwest Research Station: Portland, OR, USA, 2009; p. 15.

7. Smail, R.A.; Lewis, D.J. Forest-Land Conversion, Ecosystem Services, and Economic Issues for Policy: A Review; PNW-GTR-797; Department of Agriculture, Forest Service, Pacific Northwest Research Station: Portland, OR, USA, 2009; p. 40.

8. Forests Sourcebook: Practical Guidance for Sustaining Forests in Development Cooperation; World Bank: Washington, DC, USA, 2008.

9. Constanza, R.; de Groot, R.; Sutton, P.; van der Ploeg, S.; Anderson, S.J.; Kubidzewski, I.; Farber, S.; Turner, R.K. Changes in the global value of ecosystem services. Glob. Environ. Chang. 2014, 26, 152-158.

10. Binkley, C.S.; Aronow, M.E.; Washburn, C.L.; New, D. Global perspectives on intensively managed plantations: Implications for the Pacific Northwest. J. For. 2005, 103, 61-64.

11. Paquette, A.; Messier, C. The role of plantations in managing the world's forests in the Anthropocene. Front. Ecol. Environ. 2010, 8, 27-34.

12. Sedjo, R.A. The potential of high-yield plantation forestry for meeting timber needs. New For. 1999, 17, 339-359.

13. Carnus, J.-M.; Parrotta, J.; Brockerhoff, E.; Arbez, M.; Jactel, H.; Kremer, A.; Lamb, D.; O'Hara, K.; Walters, B. Planted forests and biodiversity. J. For. 2006, 104, 65-77.

14. Hayes, J.P.; Schoenholtz, S.H.; Hartley, M.J.; Murphy, G.; Powers, R.F.; Berg, D.; Radosevich, S.R. Environmental consequences of intensively managed forest plantations in the Pacific Northwest. J. For. 2005, 103, 83-87.

15. Fox, T.R.; Jokela, E.J.; Allen, H.L. The development of pine plantation silviculture in the southern United States. J. For. 2007, 105, 337-347.

16. Swanson, M.E.; Franklin, J.F.; Beschta, R.L.; Crisafulli, C.M.; Della Sala, D.A.; Hutto, R.L.; Lindenmayer, D.B.; Swanson, F.J. The forgotten stage of forest succession: Early-successional ecosystems on forest sites. Front. Ecol. Environ. 2011, 9, 117-125. 
17. Moore, R.D.; Richardson, J.S. Natural disturbance and forest management in riparian zones: Comparison of effects at reach, catchment, and landscape scales. Freshw. Sci. 2012, 31, 239-247.

18. Linden, D.W.; Roloff, G.J.; Kroll, A.J. Conserving avian richness through structure retention in managed forests of the Pacific Northwest. For. Ecol. Manag. 2012, 284, 174-184.

19. Welsh, H.H., Jr.; Droege, S. A case for using plethodontid salamanders for monitoring biodiversity and ecosystem integrity of North American forests. Conserv. Biol. 2001, 15, 558-569.

20. Petranka, J.W. Salamanders of the United States and Canada; Smithsonian Institution: Washington, DC, USA, 1998.

21. Pough, F.H. The advantages of ecothermy for tetrapods. Am. Nat. 1980, 115, 92-112.

22. Burton, T.M.; Likens, G.E. Energy flow and nutrient cycling in salamander populations in the Hubbard Brook Experimental Forest, New Hampshire. Ecology 1975, 56, 1068-1080.

23. Hocking, D.J.; Babbitt, K.J. Amphibian contributions to ecosystem services. Herpetol. Conserv. Biol. 2014, 9, 1-17.

24. Davic, R.D.; Welsh, H.H., Jr. On the ecological role of salamanders. Annu. Rev. Ecol. Evol. Syst. 2004, 35, 405-434.

25. Semlitsch, R.D.; Todd, B.D.; Blomquist, S.M.; Calhoun, A.J.K.; Gibbons, J.W.; Gibbs, J.P.; Graeter, G.J.; Harper, E.B.; Hocking, D.J.; Hunter, M.L.J.; Patrick, D.A.; Rittenhouse, T.A.G.; Rothermel, B.B. Effects of timber harvest on amphibian populations: Understanding mechanisms from forest experiments. BioScience 2009, 50, 853-862.

26. Welsh, H.H.; Hodgson, G.R. Woodland salamanders as metrics of forest ecosystem recovery: A case study from California's redwoods. Ecosphere 2013, 4, art59. Available online: http://dx.doi.org/10.1890/ES12-00400.1

27. Tilghman, J.M.; Ramee, S.W.; Marsh, D.M. Meta-analysis of the effects of canopy removal on terrestrial salamander populations in North America. Biol. Conserv. 2012, 152, 1-9.

28. Demaynadier, P.G.; Hunter, M.L.J. The relationship between forest management and amphibian ecology: A review of the North American literature. Environ. Rev. 1995, 3, 230-261.

29. Homyack, J.A.; Haas, C.A. Long-term effects of experimental forest harvesting on abundance and reproductive demography of terrestrial salamanders. Biol. Conserv. 2009, 142, 110-121.

30. Destefano, S. Regional and national issues for forest wildlife research and management. For. Sci. 2002, 48, 181-189.

31. Kerby, J.L.; Richards-Hrdlicka, K.L.; Storfer, A.; Skelly, D.L. An examination of amphibian sensitivity to environmental contaminants: Are amphibians poor canaries? Ecol. Lett. 2010, 13, 60-67.

32. Niemi, G.J.; McDonald, M.E. Application of ecological indicators. Annu. Rev. Evol. Ecol. Syst. 2004, 35, 89-111.

33. Bergoffen, W.W. 100 Years of Federal Forestry; Agriculture Information Bulletin No. 402; USDA Forest Service: Washington, DC, USA, 1976; p. 199.

34. McCleery, D.W. American Forests: A History of Resiliency and Recovery; USDA Forest Service and Forest History Society: Durham, NC, USA, 1992.

35. Forest Ecosystem Management: An Ecological, Economic and Social Assessment; Report of the Forest Ecosystem Management Assessment Team, USA; Department of Agriculture Forest Service: Portland, OR, USA, 1993. 
36. Moore, S.E.; Cubbage, F.; Eicheldinger, C. Impacts of Forest Stewardship Council (FSC) and Sustainable Forestry Initiative (SFI) forest certification in North America. J. For. 2012, 110, 7988.

37. Zhang, D.; Butler, B.J.; Nagubadi, R.V. Institutional timberland ownership in the US South: magnitude, location, dynamics, and management. J. For. 2012, 110, 355-361.

38. Wear, N.D.; Greis, J.G. The Southern Forests Futures Project; Wear, D.N., Greis, J.G., Eds.; USDA-Forest Service, Southern Research Station: Asheville, NC, USA, 2013; p. 552.

39. Atwood, C.; Fox, TR.; Loftis, D.L. Effects of alternative silviculture on stump sprouting in the southern Appalachians. For. Ecol. Manag. 2009, 257, 1305-1313.

40. Smith, D.M.; Larson, B.C.; Kelty, M.J.; Ashton, P.M.S. The Practive of Silviculture: Applied Forest Ecology; 9th ed.; John Wiley \& Sons: New York, NY, USA, 1997.

41. Enge, M.K.; Marion, W. Effects of clearcutting and site preparation on herpetofauna of a north Florida flatwoods. Conserv. Biol. 1986, 14, 177-192.

42. Ramovs, B.V.; Roberts, M.R. Understory vegetation and environment responses to tillage, forest harvesting, and conifer plantation development. Ecol. Appl. 2003, 13, 1682-1700.

43. Aust, M.W.; Blinn, C.R. Forestry best management practices for timber harvesting and site preparation in the eastern United States: An overview of water quality and productivity research during the past 20 years (1982-2002). Water Air Soil Pollut. 2004, 4, 5-36.

44. Forest Practices Illustrated; Washington State Department of Natural Resources, Forest Practices Division: Olympia, WA, USA, 2007; p. 152.

45. Requirements for the SFI 2010-2014 Program; Sustainable Forestry Initiative: Washington, DC, USA, 2010; p. 123.

46. FSC Principles and Criteria for Forest Stewardship; Forest Stewardship Council: Bonn, Germany, 2012; p. 37.

47. Bunnell, F.L.; Boyland, M.; Wind, E. How should we spatially distribute dead and dying wood? In Proceedings of the Symposium on the Ecology and Management of Dead Wood in Western Forests; Laudenslayer, W.F., Jr.; Shea, P.J., Valentine, B.F., Weatherspoon, C.P., Lisle, T.E., Eds; Gen. Tech. Rep. PSW-GTR-181; Pacific Southwest Research Station; Forest Service; U.S. Department of Agriculture: Albany, CA, USA, 2002; pp. 739-752.

48. Olson, D.H.; Kluber, M.R. Plethodontid salamander distributions in managed forest headwaters in western Oregon, USA. Herpetol. Conserv. Biol. 2014, 9, 76-96.

49. Ohmann, J.L.; Gregory, M.J.; Spies, T.A. Influence of environment, disturbance, and ownership on forest vegetation of coastal Oregon. Ecol. Appl. 2007, 17, 18-33.

50. Underwood, E.C.; Viers, J.H.; Quinn, J.F.; North, M. Using topography to meet wildlife and fuels treatment objectives in fire-suppressed landscapes. Environ. Manag. 2010, 46, 809-819.

51. Suming, J.; Sader, S.A. Effects of forest ownership and change on forest harvest rates, types and trends in northern Maine. For. Ecol. Manag. 2006, 228, 177-186.

52. Miller, D.A.; Wigley, T.B.; Miller, K.V. Managed forests and conservation of terrestrial biodiversity in the southern United States. J. For. 2009, 107, 197-203.

53. Perera, A.J.; Buse, L.J.; Weber, M.G. Emulating Natural Forest Landscape Disturbances; Columbia University Press: New York, NY, USA, 2004. 
54. Fischer, J.; Abson, D.J.; Butsic, V.; Chappell, M.J.; Ekroos, J.; Hanspach, J.; Kuemmerle, T.; Smith, H.G.; Wehrden, H.V. Land sparing versus land sharing: Moving forward. Conserv. Lett. 2013, 7, 149-157.

55. Phalan, B.; Onial, M.; Balmford, A.; Green, A.W. Reconciling food production and biodiversity conservation: Land sharing and land sparing compared. Science 2011, 333, 1289-1291.

56. Drever, C.R.; Peterson, G.; Messier, C.; Bergeron, Y.; Flannigan, M. Can forest management based on natural disturbance maintain ecological resilience? Can. J. For. Res. 2006, 36, 2285-2299.

57. Tittler, R.; Messier, C.; Fall, A. Concentrating anthropogenic disturbance to balance ecological and economic values: Applications to forest management. Ecol. Appl. 2012, 22, 1268-1277.

58. Gabriel, D.; Sait, S.M.; Kunin, W.E.; Benton, T.G. Food production vs. biodiversity: Comparing organic and conventional agriculture. J. Appl. Ecol. 2013, 50, 355-364.

59. Swanson, F.J.; Franklin, J.F. New forestry principles from ecosystem analysis of Pacific Northwest forests. Ecol. Appl. 1992, 2, 262-274.

60. Green, R.E.; Cornell, S.J.; Scharlemann, J.P.W.; Balmford A. Farming and the fate of wild nature. Science 2005, 307, 550-555.

61. Lindenmayer, D. Future directions for biodiversity conservation in managed forests: Indicator species, impact studies and monitoring programs. For. Ecol. Manag. 1999, 115, 277-287.

62. Kremen, C. Assessing the indicator properties of species assemblages for natural areas monitoring. Ecol. Appl. 1992, 2, 203-217.

63. Sayler, A. The reproductive ecology of the red-backed salamander, Plethodon cinereus, in Maryland. Copeia 1966, 1966, 183-193.

64. Angleberger, M.A.P.; Chinnici, J.P. Dimorphism in the red-backed salamander Plethodon cinereus (Green) at Mountain Lake, Virginia. Va. J. Sci. 1975, 26, 153-158.

65. Ruben, J.A.; Boucot, A.J. The origin of the lungless salamanders (Amphibia: Plethodontidae). Am. Nat. 1989, 134, 161-169.

66. Homyack, J.A.; Haas, C.A.; Hopkins, W.A. Influence of temperature and body mass on standard metabolic rate of eastern red-backed salamanders (Plethodon cinereus). J. Therm. Biol. 2010, 35, 143-146.

67. Stefanski, M.; Gatten, R.E.; Pough, F.H. Activity metabolism of salamanders: Tolerance to dehydration. J. Herpetol. 1989, 23, 45-50.

68. Gatten, R.E.; Miller, K.; Full, R.J. Energetics at Rest and During Locomotion, in Environmental Physiology of the Amphibians; Feder, M.E., Burggren, W.W., Eds.; University of Press: Chicago, IL, USA, 1992; pp. 314-377.

69. Homyack, J.A.; Haas, C.A.; Hopkins, W.A. Effects of experimental forest harvesting on energetics of terrestrial salamanders. J. Wildl. Manag. 2011, 7, 1267-1278.

70. Grant, E.H.C.; Nichols, J.D.; Lowe, W.H.; Fagan, W.F. Use of multiple dispersal pathways facilitates amphibian persistence in stream networks. Proc. Natl. Acad. Sci. USA 2010, 107, 6936-6940.

71. Olson, D.H.; Leirness, J.B.; Cunningham, P.B.; Steel, E.A. Riparian buffers and forest thinning: Effects on headwater vertebrates 10 years after thinning. For. Ecol. Manag. 2014, 321, 81-93.

72. Ash, A.N. Disappearance and return of plethodontid salamanders to clearcut plots in the southern Blue Ridge Mountains. Conserv. Biol. 1997, 11, 983-989. 
73. Petranka, J.W.; Eldridge, M.E.; Haley, K.E. Effects of timber harvesting on southern Appalachian salamanders. Conserv. Biol. 1993, 7, 363-370.

74. Wyman, R.L.; Hawksley-Lescault, D.S. Soil acidity affects distribution, behavior, and physiology and the salamander, Plethodon cinereus. Ecology 1987, 68, 1819-1827.

75. Burke, J.N.; Bergeron, C.M.; Todd, B.D.; Hopkins, W.A. Effects of mercury on behavior and performance of northern two-lined salamanders (Eurycea bislineata). Environ. Pollut. 2010, 158, 3546-3551.

76. Bank, M.S.; Loftin, C.S.; Jung, R.E. Mercury bioaccumulation in northern two-lined salamanders from streams in the northeastern United States. Ecotoxicology 2005, 14, 181-191.

77. Bergeron, C.M.; Bodinof, C.M.; Unrine, J.M.; Hopkins, W.A. Bioaccumulation and maternal transfer of mercury and selenium in amphibians. Environ. Toxicol. Chem. 2010, 29, 989-997.

78. Corn, P.S.; Bury, R.B. Sampling Methods for Terrestrial Amphibians and Reptiles; United States Department of Agriculture; Forest Service; Pacific Southwest Research Station: Portland, OR, USA, 1990.

79. Pearce, J.; Venier, L. Are salamanders good bioindicators of sustainable forest management in boreal forests? Can. J. For. Res. 2009, 39, 169-179.

80. Walton, B.M.; Steckler, S. Contrasting effects of salamanders on forest-floor macro- and mesofauna in laboratory microcosms. Pedobiologia 2005, 49, 51-60.

81. Best, M.L.; Welsh, H.H. The trophic role of a forest salamander: Impacts on invertebrates, leaf litter retention, and the humification process. Ecosphere 2014, 5, 16.

82. Wyman, R.L. Experimental assessment of salamanders as predators of detrital food webs: Effects on invertebrates, decomposition, and the carbon cycle. Biodivers. Conserv. 1998, 7, 641-650.

83. Hocking, D.J.; Babbitt, K.J. Effects of red-backed salamanders on ecosystem functions. PLoS One 2014, 9, e86854; doi:10.1371/journal.pone.0086854.

84. Homyack, J.A.; Sucre, E.B.; Haas, C.A.; Fox, T.R. Does Plethodon cinereus affect leaf litter decomposition and invertebrate abundances in mixed oak forest? J. Herpetol. 2010, 44, 447-456.

85. Walton, B.M. Salamanders in forest-floor food webs: Environmental heterogeneity affects the strength of top-down effects. Pedobiologia 2005, 49, 381-393.

86. Landres, P.B.; Verner, J.; Thomas, J.W. Ecological uses of vertebrate indicator species: A critique. Conserv. Biol. 1988, 2, 316-328.

87. Andelman, S.J.; Fagan, W.F. Umbrellas and flagships: Efficient conservation surrogates or expensive mistakes? Proc. Natl. Acad. Sci. USA 2000, 97, 5954-5959.

88. Murtaugh, P.A. The statistical evaluation of ecological indicators. Ecol. Appl. 1996, 6, 132-139.

89. Carignan, V.; Villard, M.-A. Selecting indicator species to monitor ecological integrity. Environ. Monit. Assess. 2002, 78, 45-61.

90. Belote, R.T.; Jones, R.H.; Wieboldt, T. Compositional stability and diversity of vascular plant communities following logging disturbance in Appalachian forests. Ecology 2012, 22, 502-516.

91. Homyack, J. Weyerhaeuser Company, Timberlands Technology, Vanceboro, NC, USA. Unpublished work, 2014.

92. Kroll, A.J.; Runge, J.P.; MacCracken, J.G. Unreliable amphibian population metrics obfuscate more than they reveal. Biol. Conserv. 2009, 142, 2802-2806. 
93. Bailey, L.L.; Simons, T.R.; Pollock, K.H. Estimating site occupancy and species detection probability parameters for terrestrial salamanders. Ecol. Appl. 2004, 14, 692-702.

94. Mazerolle, M.J.; Bailey, L.L.; Kendall, W.L.; Royale, J.A.; Converse, S.J.; Nichols, J.D. Making great leaps forward: Accounting for detectability in herpetological field studies. J. Herpetol. 2007, 41, 672-689.

95. Otto, C.R.V.; Roloff, G.J.; Thames, R.E. Comparing population patterns to processes: Abundance and survival of a forest salamander following habitat degradation. PLoS One 2014, 9, e93859.

96. Otto, C.R.V.; Kroll, A.J.; McKenny, H.C. Amphibian response to downed wood retention in managed forests: A prospectus for future biomass harvest in North America. For. Ecol. Manag. 2013, 304, 275-285.

97. Harpole, D.N.; Haas, C.A. Effects of seven silvicultural treatments on terrestrial salamanders. For. Ecol. Manag. 1999, 114, 349-356.

98. Brin, A.; Meredieu, C.; Piou, D.; Brustel, H.; Jactel, H. Changes in quantitative patterns of dead wood in maritime pine plantations over time. For. Ecol. Manag. 2008, 256, 913-921.

99. Homyack, J.A.; Paxton, B.J.; Wilson, M.D.; Watts, B.D.; Miller, D.A. Snags and cavity-nesting birds within intensively managed pine stands in eastern North Carolina, USA. South. J. Appl. For. 2011, 35, 148-154.

100. Hartley, M.J. Rationale and methods for conserving biodiversity in plantation forests. For. Ecol. Manag. 2002, 155, 81-95.

101. Forest Biomass Retention and Harvesting Guidelines for the Southeast; Forest Guild Southeast Working Group: Santa Fe, NM, USA, 2012.

102. Pavlacky, D.C., Jr.; Blakesley, J.A.; White, G.C.; Hanni, D.J.; Lukacs, P.M. Hierarchical multi-scale occupancy estimation for monitoring wildlife populations. J. Wildl. Manag. 2012, 76, $154-162$.

103. Royle, J.A.; Nichols, J.D. Estimating abundance from repeated presence-absence data or point counts. Ecology 2003, 84, 777-790.

104. MacKenzie, D.I.; Nichols, J.D.; Lachman, G.B.; Droege, S.; Royle, J.A.; Langtimm, C.A. Estimating site occupancy rates when detection probabilities are less than one. Ecology 2002, 83, 2248-2255.

105. MacKenzie, D.I.; Nichols, J.D.; Royle, J.A.; Pollock, K.H.; Bailey, L.L.; Hines, J.E. Occupancy Estimation and Modeling: Inferring Patterns and Dynamics of Species Occurrence; Elsevier: San Diego, CA, USA, 2006.

106. Gelman, A.; Carlin, J.B.; Stern, H.S.; Rubin, D.B. Bayesian Data Analysis, 2nd ed.; Chapman \& Hall/CRC: Boca Raton, FL, USA, 2004.

107. Nichols, J.D.; Bailey, L.L.; O’Connell, A.F.; Talancy, N.W., Jr.; Grant, E.H.C.; Gilbert, A.T.; Annand, E.M.; Husband, T.P.; Hines, J.E. Multi-scale occupancy estimation and modelling using multiple detection methods. J. Appl. Ecol. 2008, 45, 1321-1329.

108. Jones, L.L.C.; Leonard, W.P. Amphibians of the Pacific Northwest; Olson, D.H., Ed.; Seattle Audubon Society: Seattle, DC, USA, 2005.

109. Spies, T.A.; Franklin, J.F.; Thomas, T.B. Coarse woody debris in Douglas-Fir forests of Western Oregon and Washington. Ecology 1988, 69, 1689-1702. 
110. Homyack, J.A. Effects of Forest Regeneration Methods On Salamander Populations in Central Appalachia. Ph.D. Thesis, Department of Fisheries and Wildlife Sciences, Virginia Tech., Blacksburg, VA, USA, 2009; p. 196.

111. Maser, C.; Anderson, R.G.; Cromack, K., Jr.; Williams, J.T.; Martin, R.E. Dead and Down Woody Material, in Wildlife Habitats in Managed Forests: The Blue Mountains of Oregon and Washington; Thomas, J.W., Ed.; U.S. Department of Agriculture, Forest Service: Washington, DC, USA, 1979; p. 79-85.

112. O’Donnell, K.; Thompson, F., III; Semlitsch, R.D. Predicting variation in microhabitat utilization of terrestrial salamanders. Herpetologica 2014, 70, 259-265.

113. Owens, A.K.; Moseley, K.R.; McCay, T.S.; Castleberry, S.B.; Kilgo, J.C.; Ford, W.M. Amphibian and reptile community response to coarse woody debris manipulations in upland loblolly pine (Pinus taeda) forests. For. Ecol. Manag. 2008, 256, 2078-2083.

114. Homyack, J.A.; Aardweg, Z.; Gorman, T.A.; Chalcraft, D.R. Initial effects of woody biomass removal and intercropping of switchgrass (Panicum virgatum) on herpetofauna in eastern North Carolina. Wildl. Soc. Bull. 2013, 248, 1-9.

115. Greenberg, C.H. Response of reptile and amphibian communities to canopy gaps created by wind disturbance in the southern Appalachians. For. Ecol. Manag. 2001, 148, 135-144.

116. Hunter, M.L.J. A mesofilter conservation strategy to complement fine and coarse filters. Conserv. Biol. 2005, 19, 1025-1029.

117. Lindenmayer, D.; Hobbs, R.J.; Montague-Drake, R.; Alexandra, R.; Bennett, A.; Burgman, M.; Cale, P.; Calhoun, A.; Cramer, V.; Cullen, P.; et al. A checklist for ecological management of landscapes for conservation. Ecol. Lett. 2008, 11, 78-91.

118. Walls, S.C. Identifying monitoring gaps for amphibian populations in a North American biodiversity hotspot, the southeastern USA. Biodivers. Conserv. 2014, in press.

119. Otto, C.R.V.; Bailey, L.L.; Roloff, G.J. Improving species occupancy estimation when sampling violates the closure assumption. Ecography 2013, 36, 1299-1309.

120. Homyack, J.A. Evaluating habitat quality of vertebrates using conservation physiology tools. Wildl. Res. 2010, 37, 332-342.

121. Homyack, J.A.; Haas, C.A. Effects of repeated-stand entries on terrestrial salamanders and their habitats. Southeast. Nat. 2013, 12, 353-366.

122. Neu, J.; Jones, P.D.; Demarais, S.; Ezell, A.; Wigley, T.B. Retained woody structure in 1- to 2-year-old loblolly pine (Pinus taeda L.) plantations in Mississippi, Louisiana, and Arkansas: Implications for wildlife conservation. J. Sustain. For. 2014, 33, 152-172.

123. Bunnell, F.L.; Kremsater, L.L.; Wind, E. Managing to sustain vertebrate richness in forests of the Pacific Northwest: Relationships within stands. Environ. Rev. 1999, 7, 97-146.

124. Riffell, S.; Verschuyl, J.; Miller, D.; Wigley, T.B. Biofuel harvests, coarse woody debris, and biodiversity-A meta-analysis. For. Ecol. Manag. 2011, 261, 878-887.

125. Bunnell, F.L.; Houde, I. Downed wood and biodiversity-Implication to forest practices. Environ. Manag. 2010, 18, 397-421. 
126. Tilman, D.; Balzer, C.; Hill, J.; Befort, B.L. Global food demand and the sustainable intensification of agriculture. Proc. Natl. Acad. Sci. USA 2011, 108, 20260-20264.

(C) 2014 by the authors; licensee MDPI, Basel, Switzerland. This article is an open access article distributed under the terms and conditions of the Creative Commons Attribution license (http://creativecommons.org/licenses/by/4.0/). 